\title{
O princípio da dignidade humana e a mudança de paradigma com a Constitucionalização do Direito Civil
}

The principle of human dignity and the change of paradigm with the constitutionalization of civil law

Rafael Lamera Cabral ${ }^{1}$

\section{Resumo}

O objetivo deste trabalho é apresentar como o princípio da dignidade da pessoa humana, após ser inserido como um dos fundamentos da República Federativa do Brasil pela Constituição Federal de 1988, tem contribuído para a mudança de paradigma na interpretação do Direito Civil, relativizando o princípio da autonomia da vontade diante de questões patrimoniais e colocando os direitos humanos fundamentais como critério normativo preponderante em suas relações. Percebese que, com o desenvolvimento dessas questões, o direito privado passa pelo filtro da preservação da dignidade das pessoas, como se tem observado com a inclusão dos princípios da boa-fé, função social dos contratos e da propriedade (princípios estes que demonstram a constitucionalização do direito privado em normas constitucionais). Este paradigma está fundamentado na nova visão pós-positivista do Direito que vem gerando reações nas doutrinas do neoconstitucionalismo, e no exercício da atividade jurisdicional brasileira. A rigor, não há a superação do direito privado por ramos de direito público, mas sim uma adequação na realidade dogmática concretizada historicamente que colocava o direito civil em patamares de uma matriz liberal não contemplada pela realidade sócio-política nacional.

Palavras-chave: Constituição. Dignidade humana. Constitucionalização. Direito Privado.

\section{Abstract}

The purpose of this paper is to show how the principle of human dignity, after being inserted as one of the fundamental principles of the Federative Republic of Brazil in the Federal Constitution of 1988, has contributed to a paradigm change in the interpretation of Civil Law, relativizing the principle of autonomy of the will in front of property questions and placing the fundamental human rights as standard criterion preponderant in their relationships. It is seen that, with the development of these issues, private law is replaced by the filter of the preservation of the dignity of people, as has been observed with the inclusion of the principles of good

1 Doutorando em Direito pela Universidade de Brasília - UnB. Docente no Curso de Direito e Especialização em Direitos Humanos da Universidade Estadual de Mato Grosso do Sul - UEMS, Brasil 
faith, social function of contracts and property (these principles that demonstrate the constitutionalization of private law in constitutional rules). This paradigm is based in the new vision post-positivist of right which has been generating reactions in the doctrines of neoconstitutionalism, and in the exercise of judicial activity brazilian. Strictly speaking, there is not the overcoming of private law by branches of public law, but rather a suitability in reality dogmatic achieved historically that it posed the civil law, in increments of a liberal array not covered by socio-political realities national.

Keywords: Constitution; Human Dignity; Constitutionalization; Private Law.

\section{Introdução}

$\mathrm{Na}$ longa tradição de interpretação de normas jurídicas, dentre as quais, as constitucionais, Konrad Hesse (1991) teve uma contribuição importante para as primeiras análises de investigação após a experiência de Weimar (Alemanha) ${ }^{2}$, que constataram um novo condicionamento recíproco existente entre a ideia de Constituição jurídica e a realidade político-social de uma nação. Em um texto seminal intitulado $A$ força normativa da Constituição, de 1959, Hesse demonstra que no embate entre as reais fontes de Poder (tal como preconizado por Ferdinand Lassalle, na obra A essência da Constituição, de 1862) e a Constituição, esta não pode ser considerada a parte mais fraca.

$\mathrm{Na}$ verdade, na linhagem do pensamento de Hesse surgia o reconhecimento de que as Constituições não eram apenas documentos políticos e que, por estarem condicionadas pela realidade histórica, deveriam ser asseguradas, quando preenchido os pressupostos realizáveis, a sua força normativa. Contudo, para que fosse possível compreender este fenômeno, entendia-se que era "o Direito Constitucional [que] deveria explicitar as condições sob as quais as normas constitucionais podem adquirir a maior eficácia possível, propiciando, assim, o desenvolvimento da dogmática e da interpretação constitucional" (HESSE, 1991, p. 27).

Como é cediço, a própria existência do Direito Constitucional enquanto ramo do Direito, como ciência autônoma, foi produto recente nos ordenamentos jurídicos nacionais,

\footnotetext{
2 Não se afirma que Hesse seja pioneiro na análise entre normatividade social nas Constituições, mas tão só que seus estudos passam a ser uma referência nas interpretações da reconstrução jurídica da Alemanha sob a égide da Lei Fundamental de Bonn (1949). 
sendo cristalizados apenas no transcorrer do século XIX. As observações de Hesse surgem em um momento relevante por dois motivos: primeiro, porque decorre de um jurista alemão, cuja obra elucubrava as lembranças da Segunda Guerra Mundial e, segundo, por se tratar de uma nova especificidade para se compreender a ciência do Direito Constitucional.

O marco teórico dessa mudança orientada no modo de se visualizar os textos constitucionais se estabeleceu com o inovador pós-positivismo, tutelando, desta feita, aquilo que se convencionou a chamar pela literatura especializada de doutrina da efetividade das constituições. A partir da Segunda Guerra mundial, a ciência do Direito passou a ser modulada sob nova conjuntura, originando uma reaproximação do Direito com a moral e com a filosofia política (Gustav Radbruch), até então, rechaçada pelas leituras que se faziam da obra de Hans Kelsen (Teoria Pura do Direito).

Entretanto, convém relembrar que o estabelecimento de novas Constituições nacionais era contemporâneo às ondas de (re)democratização que se sucederam nos pósGuerra. Com isso, uma nova cultura política-jurídica foi fomentada, dando forças normativas aos direitos humanos, à jurisdição constitucional, ao controle de constitucionalidade e ao reconhecimento de direitos inéditos (direitos sociais e meio ambiente), dentre outros.

Essas considerações são importantes porque acabaram por romper com categorias clássicas da teoria do Direito até então vigente. Por outro lado, nem há que questionar sobre a manutenção ou não das divisões entre Direito Público e Direito Privado, mas sim, a de compreender que naquele contexto, um novo modelo de Estado estava sendo forjado com a incorporação de demandas que já não correspondiam à necessidade da vida contemporânea. Trata-se da alteração entre Estado Legislativo e Estado Constitucional.

No modelo de Estado Legislativo (matriz liberal, calcado no axioma da individualidade nas relações privadas), a máxima representativa se repousa na concepção do império da lei. A lei era o centro do ordenamento jurídico e devido sua própria constituição histórica, a maior relevância estava compreendida no Direito Civil, cujas bases decorriam do modelo romano-germânico, em detrimento do Direito Público, ainda em fase de incorporação aos ordenamentos jurídicos. No Estado Constitucional, a imagem de império da lei passa a ser substituída pela centralidade que a Constituição designaria aos ordenamentos jurídicos. A Constituição, neste novo formato, possui força normativa inédita, 
representação clássica de uma proteção de direitos humanos fundamentais, que passam a influenciar - diretamente - as demais produções normativas, controladas pelo sistema de constitucionalidade das leis infraconstitucionais com a Constituição.

Esses dois modelos de Estado apresentados resultam de uma mudança tripla de paradigmas, como aponta Ferrajoli (2003): a) na natureza e na estrutura do Direito, b) na natureza da ciência jurídica e na c) jurisdição. Na existência de uma interação entre transformações institucionais e culturais, o Estado Constitucional desloca a ideia principal da lei como centro do ordenamento jurídico e estabelece a Constituição como elemento basilar deste mesmo ordenamento.

Com isso, observa-se que neste embate teórico, a lei, a legalidade, passa a se subordinar às Constituições rígidas e, com isso, um novo pressuposto de coerência entre os conteúdos dessas normas jurídicas passa a ser requerido: os princípios constitucionais.

Os princípios constitucionais expressam concepções e valores que estão indissociavelmente ligados ao ambiente cultural, são frutos do pluralismo e, por isso, marcados pelo seu caráter aberto (MARINONI, 2010). Nas Constituições modernas os princípios aludem aos direitos humanos e aos princípios materiais de justiça e, por isso, revelam valores que devem conformar a realidade e orientar a compreensão e a aplicação das leis.

Com esta alteração, os princípios constitucionais também incidem a contribuir para a interpretação das regras de direito, e dentre elas, há uma mudança de paradigmas em relação às normas de direito privado, historicamente, construídas no contexto da extrema autonomia da vontade com fins patrimonialistas.

No Brasil, também foi possível constatar essa mudança de paradigma com o advento da Constituição Federal de 1988, que estabeleceu no art. 1ㅇ, III, de que a República brasileira tem como fundamento a dignidade da pessoa humana. Na prática, a adoção deste princípio como um de seus fundamentos, aponta que todas as normas jurídicas, inclusive as de direito privado, devem ser criadas, aplicadas e interpretadas conforme a Constituição. Logo, mudanças nos princípios do direito civil passaram a acontecer.

Se o próprio texto constitucional estabelece que suas ações se regem pelo princípio da prevalência dos direitos humanos e o princípio da dignidade da pessoa humana se 
estabelece como um pré-requisito para se compreender o Direito, nos termos dos três paradigmas apresentados acima por Ferrajoli (2003), dúvidas não restam e, por isso, surge a necessidade de se compreender como esse princípio passa a ser um dos instrumentos necessários para a interpretação das normas de direito privado, busca-se na literatura especializada, como bibliografias, análises de jurisprudência e artigos científicos as principais fundamentações teóricas que, a seguir, passa-se a expor.

\section{O princípio da dignidade da pessoa humana}

A partir do momento que a compreensão da lei só faz sentido se passar pelo filtro da Constituição (constitucionalidade, afinada com a gramática dos direitos fundamentais), essa relação expressa outra configuração do positivismo, que pode ser qualificada de positivismo crítico ou de pós-positivismo, não porque atribui às normas constitucionais o seu fundamento, mas sim porque submete o texto da lei a princípios materiais de justiça e direitos fundamentais, permitindo que seja encontrada uma norma jurídica que revele a adequada conformação da lei, como apontam Marinoni (2010), Ferrajoli (2003) e Enterría (2003).

Ao lado dos marcos histórico e ideológico representados por essas mudanças nos paradigmas constitucionais, vislumbra-se que, um dos princípios basilares que identificam essa transformação é o princípio da dignidade da pessoa humana. Há de se esclarecer que a dignidade humana, como aponta Barroso (2012), foi importada para o discurso jurídico devido a dois fatores principais: primeiro, pela inclusão em diferentes tratados e documentos internacionais, bem como em diversas constituições nacionais, de referências textuais à dignidade humana e segundo, por um fenômeno mais sutil, que se tornou mais visível com a ascensão de uma cultura jurídica pós-positivista, atenuando a separação radical imposta pelo positivismo pré-Segunda Guerra.

No entanto, o uso da dignidade da pessoa humana no Direito não é uníssono. Como observa Barroso (2002), vozes como as de Antonin Scalia (1997), Neomi Rao (2007) e Ruth Macklin (2003), dentre outros, assinalam que por não estar a dignidade humana no texto da Constituição americana, por exemplo, ou ainda não estar este princípio enraizado na tradição legal de um país e por fim, não ter o princípio um significado suficientemente 
específico e substantivo, seu uso deveria ser restrito ou até mesmo abandonado das interpretações das constituições.

De fato, importa salientar que muitas das possíveis críticas ao uso do princípio em apreço decorrem da falta de acordos comuns sobre seu conteúdo, sua especificidade. Mas mesmo assim, se o princípio da dignidade da pessoa humana foi incorporado à conjuntura constitucional de muitos países, o principal desafio reside na necessidade de se distinguir quais são os possíveis atributos intrínsecos à pessoa humana, cuja proteção o Direito é chamado a garantir e promover, e de que forma tais atributos devem ser, relativamente, hierarquizados (MORAES, 2003). É nesta linha de raciocínio que se encontra as principais dificuldades, ou seja, a de dar um significado razoável para justificar a utilização do princípio da dignidade humana na interpretação das normas jurídicas e, em especial, naqueles casos considerados de difícil solução.

Para que essa tarefa seja possível, nota-se ainda que os principais autores que se debruçaram sobre o tema buscaram evidenciar um conceito filosófico-político para a dignidade da pessoa humana. Não obstante, também foi possível identificar que nenhum deles compreende o princípio como um fim absoluto e somente como parte do núcleo essencial dos direitos fundamentais (como igualdade, liberdade ou privacidade), pois os princípios são normas que possuem maior ou menor peso de acordo com as circunstâncias (BARROSO, 2012; MORAES, 2003; ALEXY, 2011; DWORKIN, 2010; FERRAJOLI, 2003).

A princípio, o termo dignidade humana foi concebido pelo cristianismo, atribuindo a cada indivíduo a dignidade em um duplo fundamento: primeiro, pelo reconhecimento de que:

[...] o homem é um ser originado por Deus para ser o centro da criação; [e segundo] como é amado por Deus, foi salvo de sua natureza originária através da noção de liberdade de escolha, que o torna capaz de tomar decisões contra o seu desejo natural (MORAES, 2003, p. 111).

No entanto, em São Tomás de Aquino há uma mudança e a dignidade humana é inerente ao homem, como espécie; e ela existe só no homem enquanto indivíduo: assim, "o homem deve agora não mais olhar apenas na direção a Deus, mas voltar-se para si mesmo, tomar consciência de sua dignidade e agir de modo compatível, como aponta Moraes" 
(2003, p. 112). Na escolástica de São Tomás, diferentemente da patrística de Santo Agostinho, há o reconhecimento do governo dos homens e, por isso, o homem, por ser racional, deve ser senhor de si mesmo, viver como seu próprio rei.

Teóricos modernos também se debruçaram sobre o conceito de pessoa humana. Tanto Hobbes quanto Locke também utilizaram estas categorias. No primeiro, a dignidade da pessoa humana era usada como central para o conceito de soberania absoluta que defendia, onde a única saída para evitar a guerra, de fato, parece-lhe ser a criação do Estado, como uma entidade capaz de reduzir a vontade dos indivíduos a uma vontade única, mediante a atribuição de todos os poderes e de todos os direitos a uma única pessoa: a pessoa do soberano (MORAES, 2003; CASTRO, 2005). Já no segundo, “a palavra "pessoa" era utilizada como a que é empregada para designar aquilo que alguém chama de "si mesmo"; ele observava o ser humano individual como um ser dotado de identidade reflexiva, em virtude da consciência dessa sua identidade" (MORAES, 2003, p. 112).

Filosoficamente, é em Immanuel Kant que o conceito de dignidade da pessoa humana tem sido fundamentado. A ética, como domínio da lei moral, impõe comandos que regeriam a vontade humana em conformidade com a razão. Nesses termos, como esclarece Barroso (2012), tais comandos expressam um dever-ser, um imperativo, que pode ser hipotético ou categórico.

Para Kant (1964), os imperativos hipotéticos representam a necessidade de uma ação possível, como meio para alcançar alguma outra coisa que se pretende (ou que, pelo menos, é possível, como meio para alcançar alguma outra coisa que se pretende) ou que, pelo menos, é possível que se pretenda. Quando a ação não é boa senão como meio de obter alguma outra coisa, o imperativo é hipotético. Já o imperativo categórico seria aquele que representa uma ação como necessária por si mesma, sem relação com outro escopo, como objetivamente necessária.

Neste sentido, Kant (1964) assevera que um imperativo categórico não diz respeito à matéria da ação do indivíduo, muito menos às consequências que dela possam redundar, mas sim à forma e ao princípio donde ela resulta. O adágio kantiano de "age de tal modo que a máxima de tua vontade possa valer, simultaneamente, como um princípio para uma legislação geral" representa o imperativo categórico, "uma máxima moral da universalidade 
da conduta ética, válida em todo tempo e lugar; a afirmação da dignidade dos seres humanos como pessoas; e a atribuição à vontade humana de uma vontade legisladora geral" (MORAES, 2003, p.113).

Nota-se que no imperativo categórico o dever não se apresenta através de conteúdos fixos, nem tampouco é uma lista ou catálogo de virtudes; antes, configura-se através de uma "forma" que deve valer universal e incondicionalmente, isto é, categoricamente, para toda e qualquer ação moral (Barroso, 2012, 2005, 2007; Moraes, 2003).

No entanto, o próprio Kant se questiona se seria possível uma lei necessária para todos os seres racionais, a julgarem sempre suas ações segundo máximas que possam, eles mesmos, querer erigi-las em leis universais. Se tal lei existisse, compreende Kant (1964) que ela deveria, antes de tudo, estar ligada - inteiramente a priori - ao conceito da vontade de um ser racional em geral.

Esse ser racional em geral é o homem, que existe como fim em si mesmo, e não apenas como meio, do qual esta ou aquela vontade possa dispor a seu talento, mas em todos os seus tantos, tanto nos que se referem a ele próprio como nos que se referem a outros seres racionais. Ele deve sempre ser considerado ao mesmo tempo como fim (Kant, 1964).

Assim, o homem jamais pode ser usado ou compreendido como meio para atingir outras finalidades. Os homens não possuem valor relativo como se observa nos demais seres cuja existência não depende precisamente da vontade humana, mas da natureza (e por isso são chamadas de coisa). Isso implica afirmar que ao próprio homem, há a necessidade de se impor um limite em certo sentido a todo seu livre arbítrio (e que é objeto de respeito).

Logo, a legislação deve sempre promover a realização do valor intrínseco da dignidade humana. Na visão kantiana, a dignidade tem por fundamento a autonomia.

A moralidade consiste, pois, na relação de todas as ações com a legislação, a qual e só ela possibilita um reino dos fins. Esta legislação deve, porém encontrar-se em todo ser racional, e deve poder emanar de sua vontade, cujo princípio será o seguinte: agir somente segundo uma máxima tal que possa ser erigida em lei universal; tal, por conseguinte, que a vontade possa, mercê de sua máxima, considerar-se como promulgadora, ao mesmo tempo, de uma legislação universal. Mas, se as máximas não são já por sua natureza necessariamente conforme a este princípio objetivo dos seres racionais, considerados como autores de uma 
legislação universal, a necessidade de agir segundo aquele princípio chama-se coação prática, isto é, dever. No reino dos fins, o dever não compete ao chefe, mas sim a cada membro, e a todos em igual medida. A razão refere assim toda máxima da vontade, concebida como legisladora universal, a toda outra vontade, e também a toda ação que o homem ponha para consigo: procede assim, não tendo em vista qualquer outro motivo prático ou vantagem futura, mas levada pela ideia da dignidade de um ser racional que não obedece a nenhuma outra lei que não seja, ao mesmo tempo, instituída por ele próprio. No reino dos fins tudo tem um preço ou uma dignidade. Uma coisa que tem um preço pode ser substituída por qualquer outra coisa equivalente; pelo contrário, o que está acima de todo preço e, por conseguinte, o que não admite equivalente, é o que tem uma dignidade. Tudo o que se refere às inclinações e necessidades gerais do homem tem um preço de mercadoria; o que, embora não pressuponha uma necessidade, é conforme a um certo gosto, isto é, à satisfação que nos advém de um simples jogo, mesmo destituído de finalidade, de nossas faculdades intelectuais, tem um preço de sentimento; mas o que constitui a só condição capaz de fazer que alguma coisa seja um fim em si mesmo, isso não tem apenas simples valor relativo, isto é, um preço, mas sim um valor intrínseco, uma dignidade (KANT, 1964, p. 434).

Assim, dispõe Kant que nenhuma coisa possui valor a não ser o que lhe é assinado pela lei. Mas a própria legislação que determina todos os valores deve ter, justamente por isso, uma dignidade, isto é, um valor incondicionado, incomparável, para o qual só o termo respeito fornece a expressão conveniente da estima que todo ser racional lhe deve tributar. A autonomia é, pois, o princípio da dignidade da natureza humana, bem como de toda natureza racional (KANT, 1964).

Uma vez estruturado filosoficamente, com base nas lições kantianas, o sentido que a dignidade estabeleceria na convivência humana, resta identificar um conteúdo mínimo para que o princípio possa ser aplicado nas mais variadas situações do mundo contemporâneo.

Diante destas dificuldades Luís Roberto Barroso (2012), numa tentativa de estabelecer o conteúdo mínimo para a ideia de dignidade humana encontrou três possíveis concepções (minimalistas, confessa o autor), de que a dignidade humana identifica a) o valor intrínseco de todos os seres humanos, assim como b) a autonomia de cada indivíduo, c) limitada por algumas restrições legítimas impostas a ela em nome de valores sociais ou interesses estatais (valor comunitário).

Por valor intrínseco pode-se compreender aquilo que é dado pela natureza, não construído historicamente. No plano jurídico, Barroso (2012) aponta que o valor intrínseco 
está na origem de um conjunto de direitos fundamentais, onde todos os indivíduos têm igual valor e por isso merecem o mesmo respeito e consideração.

Para que os direitos preconizados pelo valor intrínseco possam se estabelecer, os indivíduos devem possuir autonomia; esta é entendida como o elemento ético da dignidade humana. Neste sentido, "a autonomia se estabelece como fundamento do livre arbítrio dos indivíduos, correlacionando-o à regra da autodeterminação, pois uma pessoa autônoma precisa definir as regras que vão reger a sua vida sem a intervenção de outrem" (BARROSO, 2012, p. 45).

E, por fim, o último elemento corresponde à concretização de um conteúdo social para a dignidade. O valor comunitário é moldado por uma convivência contínua de indivíduos que se relacionam e interagem nos mais variados ambientes sociais. Segundo ainda Barroso (2003, p. 42), “a dignidade como valor comunitário enfatiza, portanto, o papel do Estado e da comunidade no estabelecimento de metas coletivas e de restrições sobre direitos e liberdades individuais em nome de certa concepção de vida boa". A solidariedade estabelece um projeto social integrado por um conjunto de valores compartilhados.

Já Maria Celina Bodin de Moraes (2003), diante da noção e amplitude do princípio da dignidade da pessoa humana, vislumbra que o substrato material da dignidade poderia ser desdobrado em quatro postulados: a) $O$ sujeito moral (ético) reconhece a existência dos outros como sujeitos iguais a ele; neste caso, o princípio da igualdade corresponderia a este postulado, de modo a ser ressignificado, pois a ideia de igualdade não se assenta mais nas bases apenas formais, tornando-o mais difuso, ao contemplar, desde sempre, as diferenças existentes entre as pessoas, "evidência empírica que pode ser facilmente comprovada: os homens não são iguais entre si, e para confirmar esta assertiva basta pensar em dicotomias facilmente visualizáveis, como cultos e analfabetos, sadios e deficientes, heterossexuais e homossexuais" (MORAES, 2003, p. 119). b) Merecedores do mesmo respeito à integridade psicofísica de que é titular; neste aspecto, Moraes (2003) integra ao conceito o princípio de proteção à integridade psicofísica da pessoa humana, de modo a estendê-lo não apenas aos direitos já tradicionalmente reconhecidos, mas ampliando sua aplicação a situações novas, como as garantias aos direitos da personalidade, os relacionados ao desenvolvimento da biotecnologia, biodireito, procriação postmortem, privacidade dos dados genéticos e etc. c) $E$ 
dotado de vontade livre, de autodeterminação; a liberdade aqui estabelecida passa a ser compreendida em outro paradigma que não o da simples regulamentação de direitos subjetivos relativos aos bens materiais (conceitos patrimoniais). A questão primordial se volta a partir da necessidade de se regulamentar situações extrapatrimoniais, pois segundo Moraes (2003, apud Perlingieri, 1999, p. 298) “no centro do ordenamento está a pessoa, não como vontade de realizar-se libertinamente, mas como valor a ser preservado também no respeito a si mesma". d) É parte do grupo social, em relação ao qual tem a garantia de não vir a ser marginalizado. A esse respeito, o princípio da solidariedade torna-se fundamental, cultivado na necessidade de conceder proteção a coletividade, considerada como um patrimônio comum da humanidade.

Segundo Moraes (2003, p. 141) "a polêmica acerca dos direitos humanos, ou dos direitos da personalidade, refere-se à necessidade de normatização dos direitos das pessoas em prol da concretude do princípio da dignidade humana, de modo de melhor tutela-la".

Com as inúmeras desigualdades que são fomentadas por escolhas políticas e econômicas, estas tutelas devem ser abrangentes o suficiente para proteger, de modo especial, as minorias que ainda não foram amparadas pela concepção mais eficaz do princípio da igualdade. Assim, consumidores, mulheres, trabalhadores e todos aqueles que estiverem em situação de vulnerabilidade (econômica e social) devem ser albergados por modalidades protetivas. Como bem aponta Rocha $(2004$, p. 13) “a vida digna não é mais uma possibilidade. É um imperativo" [...] "mais grave que tudo, a coisificação do homem pode ser medida em preço. E a dignidade é qualidade do que preço não tem".

O princípio da dignidade humana é respaldado na ideia de uma consciência éticojurídica de uma determinada comunidade histórica, e por isso, não é um valor abstrato, mas sim uma autonomia ética dos homens concretos (CITTADINO, 2009).

\section{A constitucionalização do Direito Civil}

O que se entende por constitucionalização do Direito? A princípio, o termo pode ser interpretado sob múltiplas facetas e vem sendo utilizado - constantemente, nas inúmeras ondas de redemocratização que o mundo ocidental passou desde a Segunda Guerra Mundial. Neste trabalho, adota-se o entendimento de que a constitucionalização do direito 
ocorre quando no texto normativo das Constituições há a incorporação de temas que deveriam ser tratados nas normas infraconstitucionais.

A Constituição Federal de 1988 pode ser considerada como um bom exemplo onde ocorre essa constitucionalização do Direito. Mais significativa ainda se torna a análise quando se nota como essa constitucionalização afetou as normas do direito privado, dentre elas, as do direito civil.

A rigor, como adverte Barroso (2009), a constitucionalização do Direito promove amplos reflexos, tanto na esfera do legislativo, na administração pública, quanto no Judiciário. Segundo o autor, a constitucionalização:

[no legislativo] (i) limita sua discricionariedade ou liberdade de conformação na elaboração das leis em geral; e (ii) impõe-lhe determinados deveres de atuação para realização de direitos e programas constitucionais. No tocante à Administração Pública, além de igualmente: (i) limitar-lhe a discricionariedade; e (ii) impor a ela deveres de atuação; ainda (iii) fornece fundamento de validade para a prática de atos de aplicação direta e imediata da Constituição, independentemente da interposição do legislador ordinário. Quanto ao Poder Judiciário: (i) serve de parâmetro para o controle de constitucionalidade por ele desempenhado (incidental e por ação direta), bem como (ii) condiciona a interpretação de todas as normas do sistema. Por fim, para os particulares, estabelece limitações à sua autonomia da vontade, em domínios como a liberdade de contratar ou o uso da propriedade privada, subordinando-a a valores constitucionais e ao respeito a direitos fundamentais. (BARROSO, 2009, p. 62).

Gustavo Tepedino aponta que com a constitucionalização presente na Constituição de 1988, três questões significativas aconteceram: a primeira é "a descoberta do significado relativo e histórico dos conceitos jurídicos que antes eram vistos como neutros e absolutos"; a segunda conquista "é a superação da rígida dicotomia direito público e o direito privado"; e a terceira conquista refere-se a adoção "de valores que presidem a iniciativa econômica, a família, a propriedade e demais institutos do direito civil”. (TEPEDINO, 2003, p. 119).

Com a constitucionalização do Direito Civil, temas como família, função social do contrato e da propriedade, direitos da personalidade, entre outros, passam a ser inseridos no texto constitucional e com a moderna hermenêutica jurídica produzida pelas opções do neoconstitucionalismo, os princípios também passam a atuar diretamente no fim teleológico dos ordenamentos jurídicos. 
Assim, a expressão jurídica do princípio da dignidade da pessoa humana passa a influenciar toda a produção do Direito dentro da ordem jurídica nacional e, desta forma, não há como negar que, se é elemento indispensável para a criação, também assim o deve ser considerado quando da aplicação e interpretação do Direito. São nestes termos que se tem observado a influência do princípio da dignidade humana na aplicação do direito privado, pois este princípio "impõe transformação radical na dogmática do direito civil, estabelecendo uma dicotomia essencial entre as relações jurídicas existências e as relações jurídicas patrimoniais" (TEPEDINO, 2007, p. 76).

As transformações estão sendo incorporadas especificamente nas relações contratuais, de propriedade, no direito de família e no conteúdo da personalidade dos cidadãos. Como exemplifica Tepedino (2007), a noção de autonomia da vontade, como concebida nas codificações do século XIX, dá lugar à autonomia privada alterada substancialmente nos aspectos subjetivo, objetivo e formal.

Nestas relações, as pessoas objeto do direito civil deixam de ser consideradas em sua abstração (identificadas pela igualdade formal) e passam a ser reconhecidas concretamente, no contingente da igualdade material, subtraindo, desta forma, desigualdades inaceitáveis nas mais variadas relações contratuais (ex. a relações dos consumidores).

Nas relações contratuais, por exemplo, a nova hermenêutica civil constitucional aponta uma readequação no modos operandi de se compreender o a) princípio da autonomia da vontade (entendido como a prerrogativa que tem os indivíduos de criarem relações na órbita do direito, desde que de acordo com a lei, ou que com ela não contrariem); o b) princípio da obrigatoriedade da convenção, respaldado pela máxima do pacta sunt servanda, que vem sendo relativizado diante do c) princípio do equilíbrio contratual, ou da equivalência material das prestações, onde a força vinculante dos contratos pode ser contida pelo magistrado em certas circunstâncias excepcionais ou extraordinárias, que impossibilitem a previsão de excessiva onerosidade no cumprimento da prestação. Trata-se da teoria da imprevisão que, ao passar a ser norma legal (cuja expressão 
mais frequente é a cláusula rebus sic stantibus ${ }^{3}$ ) impõe-lhe restrições e dá ao juiz, excepcionalmente, um poder de revisão por imprevisibilidade (CC, art. 317) sobre os atos negociais, havendo desigualdade superveniente das obrigações contratadas e consequente enriquecimento ilícito de um dos contraentes, podendo ainda decretar a resolução do contrato (CC, art. 478) (DINIZ, 2009). E ainda com a observação do d) princípio da boa-fé, adotado expressamente pelo Código Civil de 2002, (art. 422), que corresponde à exigência que tem as partes de agir com correção, com dignidade, honestidade e boa intenção nas relações negociais.

A função social da propriedade e a dos contratos, como bem observa Diniz (2009) constituem limites à autonomia da vontade, na qual se funda a liberdade contratual, que deverá estar voltada à solidariedade (CF, art. 3ํㅗ. I), à Justiça social (CF, art. 170, caput), à livre iniciativa, ao progresso social, à livre circulação de bens e serviços, à produção de riquezas, ao equilíbrio das prestações, evitando o abuso do poder econômico, a desigualdade entre os contratantes e a desproporcionalidade, aos valores jurídicos, sociais, econômicos e morais, ao respeito à dignidade da pessoa humana.

Neste sentido, o homem, especialmente nas relações de direito privado, não pode mais ser submetido como meio de exploração econômica por outrem. Em um exemplo clássico kantiano, cita-se uma das situações em que o imperativo categórico (em que consiste a dignidade humana) pode ser mais bem compreendido nas relações privadas. Imaginem um

[...] homem que é impelido pela necessidade a pedir dinheiro emprestado. Sabe que não poderá restituí-lo, mas sabe igualdade que nada lhe será emprestado, se não tomar o sério compromisso de satisfazer a dívida dentro de determinado prazo. Sente vontade de fazer essa promessa, mas tem ainda bastante consciência para a si mesmo perguntar se não será proibido e contrário ao dever tentar safarse da necessidade por meio de tal expediente. Supondo que tome esta decisão, a máxima de sua ação significaria isso: quando penso estar em falta de dinheiro, peço emprestado, prometendo restituí-lo, embora sei que nunca o farei. Ora, é bem possível que este princípio do amor de si ou da utilidade própria se prenda como todo o meu bem-estar futuro, mas, de momento, a questão consiste em sabe se isso é justo. Transformo, pois, a exigência do amor de si em lei universal e ponho a questão seguinte: que sucederia se minha máxima se convertesse em lei universal? Imediatamente vejo que ela nunca poderia valer como lei universal da

3 Significa "estando as coisas assim" ou "enquanto as coisas estão assim"; esta cláusula corresponde à formula de que, nos contratos de trato sucessivo ou a termo, o vínculo obrigatório ficará subordinado, a todo tempo, ao estado de fato vigente à época de sua estipulação. 
natureza e estar de acordo consigo mesma, mas que deveria necessariamente contradizer-se (KANT, 1964, p. 422).

Isso significa que, como fundamento básico de todas as máximas das ações, se deve assentar que o sujeito dos fins, ou seja, o próprio ser racional, nunca deve ser tratado como simples meio, mas como condição limitativa suprema no uso de todos os meios, o mesmo é dizer que deve sempre ser tratado como fim (KANT, 1964). É esta limitação que a constitucionalização do Direito Civil tem estabelecido nas relações contratuais, com a inclusão de princípios constitucionais, tal como o da dignidade humana, diante das complexas relações patrimoniais estabelecidas. O homem, em suas relações privadas, em sua dignidade, deve ser a condição limitativa dos meios possíveis para atender suas necessidades.

Questão não menos complexa se refere aos direitos da personalidade enquanto uso do princípio da liberdade individual. Atualmente, este princípio tem se "consubstanciado na perspectiva da privacidade, da intimidade, de livre exercício da vida privada" (MORAES, 2003, p. 136). E neste aspecto, muitos exemplos podem ser citados como situações violadoras da dignidade humana em razão da lesão ao princípio da liberdade. Casos como as revistas íntimas a empregados ou até mesmo a necessidade de se submeter a exames toxicológicos determinados pelo empregador, submissão a teste de bafômetro, dentre outros, podem ser arrolados neste sentido (MORAES, 2003).

Entretanto, devido a própria falta de regulamentação normativa, violações ao direito de liberdade também podem ser direcionados a incapacidade de controle acerca dos próprios dados pessoais, dos chamados "dados sensíveis", como indica Moraes (2003). Dados pessoais, como número de identificações civis (RG, CPF, entre outros), ou até mesmo endereço de e-mails, com o recebimento de spam, constituem exemplos dessas violações. Mas esses dados sensíveis podem também se referir aos dados genéticos.

Em 2002, na cidade de Goiânia-GO, o emblemático caso "Pedrinho" pode ser demonstrado nesta perspectiva de violação da liberdade. Pedrinho era uma criança que foi sequestrada no hospital em que nasceu. Quando desvendada a autoria do crime de sequestro, que apontou Vilma Martins da Costa como a autora do crime, mãe de criação de 
Pedrinho, dúvidas também surgiram sobre a maternidade de outra filha de Vilma, Roberta Jamily, irmã de Pedrinho, que também poderia ter sido vítima de sequestro.

No inquérito que apurou os fatos, Roberta se negou a fornecer o DNA para investigação. Quando ouvida na delegacia, deixou resto de cigarro no cinzeiro, e o delegado, recolhendo o material, diante da saliva de Roberta contida no cigarro, encaminhou à perícia técnica, que após estudos, apontou que a jovem não era filha de Vilma, mulher que a criou. Neste caso emblemático, a defesa de Roberta contestou o exame de DNA que foi obtido sem o seu consentimento, violando seu direito de não fazer prova contra si. No entanto, os Tribunais superiores julgaram válido o exame, sob a alegação de que com o descarte do cigarro, haveria uma parte desintegrada do corpo humano, e por isso,

[...] não há, nesse caso, nenhum obstáculo para sua apreensão e verificação (ou análise ou exame). São partes do corpo humano (vivo) que já não pertencem a ele. Logo, todas podem ser apreendidas e submetidas a exame normalmente, sem nenhum tipo de consentimento do agente ou da vítima. $O$ caso Roberta Jamily (o delegado se valeu, para o exame do DNA, da saliva dela que se achava nos cigarros fumados e jogados fora por ela) assim como o caso Glória Trevi (havia suspeita de que essa contora mexicana, que ficou grávida, tinha sido estuprada dentro do presídio; aguardou-se o nascimento do filho e o DNA foi feito utilizando-se a placenta desintegrada do corpo dela) são emblemáticos: a prova foi colhida (obtida) em ambos os casos de forma absolutamente lícita (legítima) (cf. Castanho Carvalho e, quanto ao último caso, STF, Recl. 2.040-DF, rel. Min. Néri da Silveira, j. 21.02.02). (CUNHA; GOMES, 2012, p. 1).

Em que pese este caso ter sido midiatizado, a máxima preponderante é que o Estado não está impedido de usar vestígios para colher material útil na identificação de indivíduos, como de fato aconteceu. Contudo, o que se questiona é até que ponto o uso desses dados sensíveis podem ser utilizados (e como) nas relações privadas.

Por fim, essas alterações também ocorrem na atuação da jurisdição. reconhecimento da interrupção da gravidez de anencéfalos, ou até mesmo na possibilidade do casamento entre pessoas do mesmo sexo (novas entidades familiares), como julgados recentemente pelo Supremo Tribunal Federal, tem demonstrado que na aplicação da lei infraconstitucional, a leitura dos dispositivos jurídicos tem sido respaldada pelo princípio constitucional da dignidade humana (em cotejamento com o fundamento teleológico dos direitos humanos), relativizando regras que, em um primeiro momento, poderiam afetar a 
plena realização do ser humano, ou até mesmo, ter efeitos diretos ou indiretos em questões patrimoniais.

\section{Considerações finais}

Em fase de considerações finais, tem-se observado que o princípio da dignidade humana deve ser compreendido como uma cláusula geral de tutela da pessoa humana e deve prevalecer tanto nas situações jurídicas conflituosas existenciais quanto patrimoniais. A leitura moral de Constituições, que preconizam a dignidade humana como fundamento constitutivo de sua organização política-jurídica, inaugura uma nova etapa no modo de se pensar o Direito, a sua ciência e sua aplicação (jurisdição). Aliás, como ressalta Tepedino (2007, p. 80), a aplicação direta de normas constitucionais oportuniza "a inserção permanente e continua da tábua axiológica constitucional nas categorias do direito privado, processo que se identifica com o advento de novos diplomas legislativos, codificados ou extracodificados".

Em um mundo em constante transformação política-social não é crível a defesa ou a manutenção de modelos jurídicos cristalizados que não correspondem mais às necessidades humanas. Com o direito civil isso não é e nem pode ser diferente. O que se tem observado com o advento da Constituição Federal de 1988 é que, com a doutrina da efetividade das Constituições, todas as normas jurídicas, consideradas válidas sob a perspectiva constitucional, ao passarem pela filtragem dos direitos humanos, devem ser consideradas como pressuposto para a interpretação das demais normas, pois adota-se, também, o princípio da eficácia horizontal dos direitos fundamentais.

Com a inserção do princípio da dignidade humana como fundamento da República, a linguagem constitucional estabeleceu parâmetros inovadores, cujo efeito, ao ser aplicado ao direito civil, possibilitou o termo constitucionalização do direito civil.

Esses novos contornos da ordem pública sob a órbita do direito privado, em nenhum momento, pode ser considerada como perda de espaço desse ramo do Direito. Aliás, com "a promulgação do Código Civil de 2002, [o que se impôs foi] a reflexão dos paradigmas axiológicos que devem nortear o intérprete na reconstrução dos institutos de direito privado. [...] A este respeito, deve-se observar que o direito civil assistiu ao 
deslocamento de seus princípios fundamentais do Código Civil para a Constituição" (TEPEDINO, 2007, p. 71).

\section{Referências}

ALEXY, Robert. Teoria dos direitos fundamentais. São Paulo: Malheiros, 2011.

ANTUNES ROCHA, Cármen Lúcia (Coord.). O Direito à Vida Digna. Belo Horizonte: Editora Fórum, 2004.

BARROSO, Luís Roberto. A doutrina brasileira da efetividade. In: Temas de direito constitucional, t. III. Rio de Janeiro: Renovar, 2005.

Aqui, lá e em todo lugar: a dignidade humana e no direito contemporâneo e no discurso transnacional. Mensagem pessoal - e-mail, recebida em 20.04.2012.

. Da falta de efetividade à judicialização excessiva: direito à saúde, fornecimento gratuito de medicamentos e parâmetros para a atuação judicial. Interesse Público, v. 36, n. 31, 2007.

Neoconstitucionalismo e constitucionalização do Direito: o triunfo tardio do direito constitucional no Brasil. In: QUARESMA, Regina et al. (Coord.). Neoconstitucionalismo. 1. ed. Rio de Janeiro: Forense, 2009.

CASTRO, Marcus Faro de. Violência, Medo e Confiança: Do Governo Misto à Separação dos Poderes. Revista Forense, Rio de Janeiro, v. 382, p. 157-180, 2005.

CITTADINO, Gisele. Pluralismo, Direito e Justiça distributiva: elementos da filosofia constitucional contemporânea. Rio de Janeiro: Lumen Juris, 2009.

CUNHA, Rogério Sanches; GOMES, Luiz Flávio. Lei 12.654/12 (identificação genética): nova inconstitucionalidade (?). Disponível em:

<http://atualidadesdodireito.com.br/lfg/2012/06/04/lei-12-65412-identificacao-geneticanova-inconstitucionalidade>. Acesso em: 10 maio 2012.

DAHL, Robert. A democracia e seus críticos. São Paulo: WMF Martins, 2010.

DINIZ, Maria Helena. Curso de Direito Civil brasileiro - Teoria das obrigações contratuais e extracontratuais. São Paulo: Saraiva, 2009. v. 3. 
DWORKIN, Ronald. Levando os direitos a sério. São Paulo: WMF Martins, 2010.

ENTERRÍA, Eduardo García de. La Constitución española de 1978 como pacto social y como norma jurídica. Madrid: Inap, 2003.

FERRAJOLI, Luigi. Pasado y futuro del Estado de Derecho. In: CARBONELL, Miguel (Coord.). Neoconstitucionalismo(s). Madrid: Trotta, 2003.

KANT, Immanuel. Fundamentação da metafísica dos costumes. Tradução: Antônio Pinto de Carvalho. Lisboa: Companhia Editora Nacional, 1964.

HESSE, Konrad. A força normativa da Constituição. Porto Alegre: Sérgio Antônio Fabris Editor, 1991.

MACKLIN, Ruth. Dignity Is a Useless Concept. British Medical Journal, n. 327, 2003.

MARINONI, Luiz Guilherme. Teoria Geral do Processo. São Paulo: RT, 2010.

MORAES, Maria Celina Bodin de. Conceito de dignidade humana: substrato axiológico e conteúdo normativo. In: SARLET, Ingo. Constituição, direitos fundamentais e direito privado. Porto Alegre: Livraria do Advogado Editora, 2003.

RAO, Neomi. On the use and abuse of dignity in Constitucional Law. Columbia Journal of European Law, n. 14, 2007.

SCALIA, Antonin. A matter of interpretation: Federal Courts and the Law. University Center for Human Values, 1997.

TEPEDINO, G. A Constitucionalização do Direito Civil: perspectivas metodológicas interpretativas diante do novo código. In: FREIRE DE SÁ, Maria de Fátima; FIÚZA, César; NAVES, Bruno Torquato de Oliveira. Direito Civil: Atualidades. Belo Horizonte: Del Rey, 2003.

. Normas constitucionais e direito civil na construção unitária do ordenamento.

Revista de Direito do Estado, v. 2, n. 07, 2007.

Artigo recebido em 23/07/2012 e aprovado para publicação em 30/11/2012. 
